Document downloaded from:

http://hdl.handle.net/10251/77481

This paper must be cited as:

Carranza Concha, J.; Camacho Vidal, MM.; Martínez Navarrete, N. (2012). EFFECTS OF BLANCHING ON GRAPES (VITIS VINIFERA) AND CHANGES DURING STORAGE IN SYRUP. Journal of Food Processing and Preservation. 36(1):11-20. doi:10.1111/j.17454549.2011.00546.x.

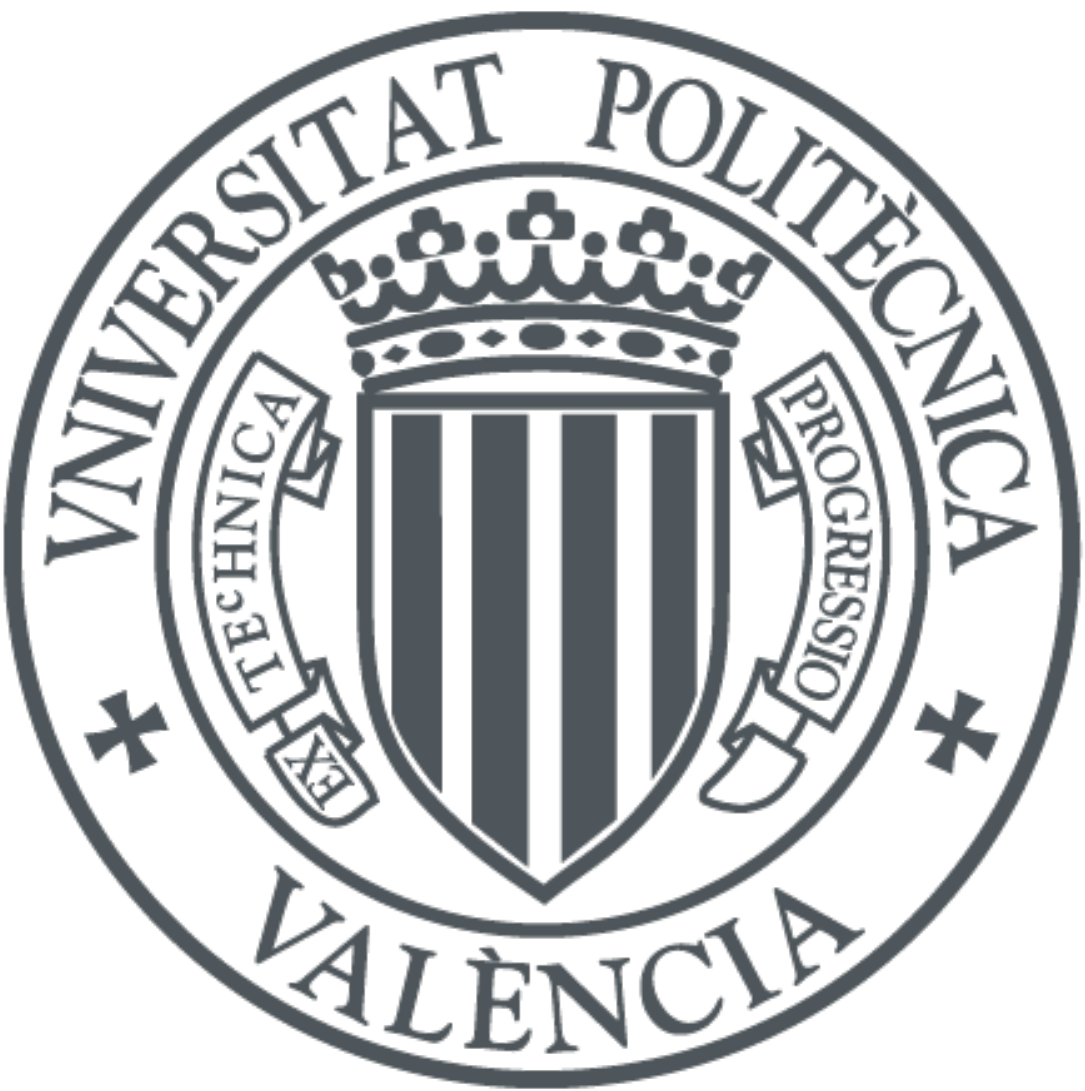

The final publication is available at

https://dx.doi.org/10.1111/j.1745-4549.2011.00546.x

Copyright Wiley

Additional Information 


\title{
EFFECTS OF BLANCHING ON GRAPES (Vitis vinifera) AND CHANGES DURING STORAGE IN SYRUP
}

\section{JOSÉ CARRANZA-CONCHA, MARÍA DEL MAR CAMACHO and NURIA MARTÍNEZ- NAVARRETE ${ }^{1}$}

\author{
Department of Food Technology \\ Food Investigation and Innovation Group \\ Universidad Politécnica de Valencia, \\ Camino de Vera 14, 46022 Valencia, Spain.
}

\begin{abstract}
This paper studies the effects of conventional and microwave blanching on grapes that are being processed for storage in syrup. An analysis was made of the blanching effects on macro and micronutrients, as well on colour and mechanical properties. To test the effectiveness of these blanching treatments, enzymatic residual activity was measured for polyphenol oxidase, peroxidase and pectinmethylesterase. Both blanching treatments reduced enzyme activity in the grapes, especially polyphenol oxidase (99\%). Blanching treatments also caused significant decrease in tartaric acid also as colour and mechanical changes, more marked in conventional treated samples. As for the effect of storage, microwave treatment supposed a greater stability of tartaric acid and total phenols than conventional one, also as a greater antioxidant activity of grapes. From this point of view, microwave treatment of samples immersed in water can be proposed as a good alternative to conventional heating in boiling water for grapes blanching.
\end{abstract}

\section{PRACTICAL APLICCATIONS}

Blanching is a relatively mild treatment, which aim is to inactivate enzymes that would cause a decrease of final product quality. The microwave energy has attracted considerable interest because of the penetration capacity of waves, heating not only the food surface but also the inner part. This speeds up the drying process and contributes to improve the quality of the product. The results of this study showed that microwave blanching of grapes when immersed in water has advantages as compared to conventional treatment. Enzyme inactivation achieved with this kind of energy was very similar in both cases but microwave treatment supposed a greater stability of tartaric acid and total phenols than conventional one, also as a greater antioxidant activity of grapes.

Keywords: microwave, enzymatic activity, mechanical properties, colour, phenols, antioxidant activity, tartaric acid.

\section{INTRODUCTION}

Heat treatment is one of the processes used for food preservation. This process enables the elimination of many categories of micro-organisms and also inactivates enzymes that could alter the product. Peroxidase (POD) and polyphenol oxidase (PPO)

\footnotetext{
${ }^{1}$ Corresponding author: TEL: +34 963879362, FAX: +34 96387369, E-MAIL: nmartin@tal.upv.es (N. Martínez-Navarrete)
} 
are considered indicators of the effectiveness of heat treatment. Peroxidase is the most significant because of its resistance to heat and its regenerative capacity (Viña et al., 2007). Its total destruction ensures the inactivation of existing enzymes. However, some studies show that this enzyme is not usually responsible for the main degradation reaction in fruit. Therefore, the total inactivation of peroxidase is a process with unnecessary consequences on the quality of the fruit, especially the texture (Viña et al., 2007). Enzymatic browning in fruits is mostly caused by polyphenol oxidase (Filiz et al., 2008; Walker, 1995; Cash et al., 1976; Valero et al., 1988; Yokotsuka et al., 1991). This enzyme is present in all plants (Whitaker, 1972), but it is particularly active in those fruits and vegetables that contain high levels of phenolic compounds, as is the case of grapes (Cantos et al., 2002; Maxcheix et al. , 1990). Moreover, the action of enzymes such as pectinmethylesterase (PME) which are found in many fruits and vegetables (Rexova-Benkova and Markovich, 1976) has a major effect on the texture of fresh and processed products.

The most common technique to inactivate enzymes is blanching, which is considered a pre-treatment. This is accomplished by placing the product in hot or boiling water (85-100 ${ }^{\circ} \mathrm{C}$ ); in acid or basic hot or boiling solutions, steam (Kidmose and Martens, 1999) or by microwave heating with immersion in water or solutions for a few seconds or minutes (Ramaswany and Van de Voort, 1990; Ponne et al., 1991; Severini et al., 2001). These manipulations do not constitute a preservation method and are usually pre-treatments applied for the preparation of the raw material before other conservation operations are performed, such as sterilization, dehydration, and freezing.

Short blanching exposure times are effective for reducing degradation reactions during storage. However, blanching also produces changes in the cellular structure and composition (Philippon, 1984). The heat received during blanching also inevitably causes some changes in the sensory and nutritional characteristics. It is often necessary to find the appropriate technology and time period for each product and establish a balance between enzyme inactivation and the minimization of losses in the quality and attributes of the product.

Various blanching methods have been studied to improve product quality and microwave treatment remains an interesting alternative to conventional processing. The penetration of microwaves causes rapid heating, but seems to have a non-thermal effect on the inactivation of enzymes. This reduces both, processing time and the impact of temperature, with a consequent improvement in the retention of thermolabile substances and sensory characteristics (Heedleson and Doores, 1994). The disadvantage of microwave treatments is that it is difficult to discover the distribution of the energy field (Zhang et al., 2006) and, in addition, these treatments suffer limited repeatability and high costs. Lin and Brewer (2005) mention that microwave blanching enables efficient heat transfer with little or no water, which reduces nutrient loss compared to the traditional method. There is some controversy regarding the mechanism of action and effect in microwave treatments; and there is scarce literature in comparison with studies on the effect of conventional heat treatments.

This work aims to contribute to knowledge about the use of microwaves as an alternative process to conventional grape blanching for the preparation of the product in syrup. The preservation of fruit in syrup reduces the available water through the addition of sugar. The immersion of fruit in syrup gives rise to the phenomena of mass transfer due to the spontaneous equilibrium created between the two materials. Water and soluble compounds are transferred from the less concentrated medium to the more concentrated solution (osmosis). Solutes from the syrup may also be transferred to the fruit. The final product acquires organoleptic characteristics that are appreciated by 
consumers. However, the process could be improved if the previous blanching of the product is carried out in such way that less damage was caused to product quality.

\section{MATERIAL AND METHODS}

\section{Raw materials}

The experiments were made from Festival Seedless white grapes (Vitis vinifera). These were purchased in a supermarket in Valencia. Grapes were selected with the typical external features of white grapes and were similar in firmness and size. The grapes were rinsed with distilled water before use and then dried with absorbent paper for further processing and analysis. The syrup measured $16{ }^{\circ}$ Brix and was made from distilled water $(84 \% \mathrm{w} / \mathrm{w})$ and common food-grade sugar $(16 \% \mathrm{w} / \mathrm{w})$ which was dissolved by continuous stirring at $30^{\circ} \mathrm{C}$. Two commercial brands of grape in syrup were obtained for comparison with the experimental product.

\section{Processing}

Traditional blanching (TB): The grapes (100 g) were submerged in a Selecta Precisterm bath with distilled water at $100^{\circ} \mathrm{C}$ for 2 minutes and 30 seconds. Subsequently, the grapes were cooled rapidly in an ice bath (3-5min) and dried for analysis or immediate storage.

Microwave blanching (MWB). Two methods were tested: a direct heating method and heating while immersed in water. For the first one, the grapes $(100 \mathrm{~g})$ were placed in a domestic microwave oven (Moulinex 5141) on a circular grid, with the aim of achieving more uniform heating. Microwave power (W)-process time (s) applied were 300-45, 500-30, 500-45, 700-30, 700-45 and 900-30. After the treatment, the product was cooled in an ice bath and dried for later analysis. For microwave blanching with water, grapes (100 g) were added to containers with $300 \mathrm{~g}$ of distilled water and then placed in the same microwave oven that had been used for direct heating. They were then heated for two minutes and $50 \mathrm{~s}$ or three minutes at $900 \mathrm{~W}$. The hot water was then eliminated and grapes were cooled in ice water for $3-5 \mathrm{~min}$ and then dried for later analysis.

The effectiveness of the blanching treatments was evaluated by measuring the activity of pectinmethylesterase (PME), peroxidase (POD), and polyphenol oxidase (PPO) enzymes before and after processing.

Grapes blanched by the traditional method and by the microwave methods were stored at room temperature in syrup ( $16{ }^{\circ}$ Brix) for $1,4,7,15$ and 21 days in sealed plastic containers for later analysis.

\section{Analyses}

The fresh samples, the newly processed samples and those stored for 1, 4, 7, 15 and 21 days were analysed as follows.

PME, POD, and PPO were measured using the methods described by Kimball (1999), Elez-Martínez et al. (2006) and Rapeanu et al. (2006) respectively. In all cases, the results of enzyme analyses were expressed as residual enzyme activity (REA) using Eq. (1).

$$
R E A=100 * \frac{A_{T}}{A_{0}}
$$


Where $A_{T}$ and $A_{0}$ are the enzyme activity calculated from the slope of the linear portion of the curve absorbance at $400 \mathrm{~nm}$ vs. time of the blanched and fresh grapes, respectively.

The water content was measured following AOAC method for fruits rich in sugar (20013 AOAC, 1980). The soluble solids of the liquid phase of the grapes and the syrup ( ${ }^{\circ}$ Brix) were measured at $20^{\circ} \mathrm{C}$ using a refractometer (Atago NAR-3T, Japan) and water activity $\left(\mathrm{a}_{\mathrm{w}}\right)$ by using a dew-point hygrometer (GBX FA-st lab, France). Total acidity was determined by titrating with $\mathrm{NaOH}(0.1 \mathrm{~N})$ and the result was expressed in milligrams of the main acid (tartaric acid, TA) per $100 \mathrm{~g}$ of sample (AOAC, 1997). Total pectin content was analyzed by quantifying the galacturonic acid residues (AGU) following the procedure used by $\mathrm{Yu}$ et al. (1996). To determine the AGU (AGU mg/100g of sample) a Thermo Spectronic UV1 spectrophotometer was used to measure the absorbance of the samples at $520 \mathrm{~nm}$.

The extraction for quantification of total phenols (TPh) was made using the technique developed by Peiró et al (2006). This same extract was used for measuring antioxidant activity (AOA). The TPh was quantified using the Folin-Ciocalteu analysis (Li et al, 2006) and was expressed in mg of gallic acid/100g fresh grapes. Antioxidant activity was determined using a modification of the spectrophotometric technique developed by Re et al. (1999) using the radical $\mathrm{ABTS}^{+}$(Sigma) generated by potassium persulfate $\left(\mathrm{K}_{2} \mathrm{~S}_{2} \mathrm{O}_{8}\right) 2.45 \mathrm{mM}$. The results were expressed as antioxidant activity equivalent to an mg of Trolox (TEAC) in $100 \mathrm{~g}$ of fresh sample.

Colour was measured from the CIE $\mathrm{L} * \mathrm{a} * \mathrm{~b} *$ coordinates $\left(\mathrm{L}^{*}, \mathrm{a} * \mathrm{~b}, \mathrm{C} *{ }_{\mathrm{ab}}\right.$ and $\mathrm{h} * \mathrm{ab}$ ) obtained with a $10^{\circ}$ observer and D65 illuminant. A CM-1000R spectrophotometer with a low reflectance glass CR-A51/1829-752 between samples and equipment (Konica Minolta Sensing, Inc., Osaka, Japan) was used. These measurements were made in the equatorial zone on the skin of the grape. Textural properties analysis was conducted with a puncture test using a $6 \mathrm{~mm}$ diameter probe with a relative penetration of $95 \%$ at $2 \mathrm{~mm} / \mathrm{s}$. A Stable Micro Systems texture analyzer model TA-XT2 (Surrey, England) was used. The fracture force was obtained from the curve, as well as the slope of the initial straight part of the curve, related to the deformability of the sample before fracture.

Commercial grape in syrup products were also analyzed to obtain benchmarks. In this case, soluble solids, $\mathrm{a}_{\mathrm{w}}$, total acidity, total phenols, antioxidant activity, colour and mechanical properties were analysed using the methods described above.

The ${ }^{\circ}$ Brix, $a_{w}$, total acidity, total phenols and antioxidant activity in the syrup of our experimental product and the commercial products were also analyzed.

All results were statistically analyzed using the Statgraphics Plus program version 5.1.

\section{RESULTS}

For direct microwave heating it was observed that enzymatic activity generally diminished when heating time and microwave power increased, although the decreases were insufficient. Rates of inactivation of $67 \pm 0.4,67 \pm 9$ and $40 \pm 2$ for the PPO, POD, and PME, respectively, were reached under the most aggressive conditions studied (900W and 30s). The skins of the grapes were completely torn and many grapes lost some of their juice in the samples treated at more than $700 \mathrm{~W}$. Furthermore, temperature differences of up to $20^{\circ} \mathrm{C}$ were observed in grapes in the same blanching batch. These differences may be caused by the variability of the impact of microwaves acting without a water barrier. This may be explained by the known heterogeneity of microwave heating and which is one of the disadvantages of this technology (Zhang et al., 2006). 
These temperature differences explain the high variability observed in the rate of enzyme inactivation produced with these treatments. As a result, the procedure of blanching grapes by directly heating in the microwave was rejected.

The two treatments of microwave blanching in water $(900 \mathrm{~W} / 2 \mathrm{~min} 50 \mathrm{~s}$ and $900 \mathrm{~W} / 3 \mathrm{~min}$ ) showed no significant differences in the inactivation of enzymes and both treatments exceeded $80 \%$. Therefore, the gentler treatment (900W/2min50s) was selected as the most appropriate because it was expected to cause the minimum of damage to the thermolabile substances of the grape. POD enzyme activity is critical in grapes and this enzyme showed the greatest thermal resistance.

\section{Effect of blanching on the quality parameters of grapes}

The results of enzymatic inactivation for the two blanching treatments confirmed that while the traditional method has a significant $(\alpha<0.05)$ greater effect than the microwave method on PME and POD, the rates of PPO inactivation remained equal ( $\alpha>0.05$ ) for both. This is especially true for the PPO enzyme where inhibition rates of $99.90 \pm 0.05$ for microwave methods and $99.80 \pm 0.01 \%$ for traditional methods were obtained. PME inactivation rates were $63 \pm 5$ and $70.8 \pm 1.6$; while POD rates were $81.7 \pm 1.4$ and $86.7 \pm 0.9$ for microwave blanching and traditional blanching methods, respectively.

Table 1 shows the mean values of the compounds and parameters analyzed for fresh grapes and grapes blanched traditionally and with microwaves. The ANOVAs showed significant differences in soluble solid content and water content. However, the differences were small and may be due more to the variability of the grapes than the effect of the treatments. In fact, water activity showed no significant differences.

Tartaric acid decreased $(\mathrm{p}<0.05)$ after both treatments. This may be due to the effect of temperature that may affect organic acids, most sensitive to temperature despite the treatment is rapid. However, the phenomenon of leaching may also be a factor. The loss of this acid was greater in the microwave treatment $(\mathrm{p}<0.05)$.

No significant differences between the blanched and fresh samples were observed for the other analysed compounds and antioxidant activity. This is not surprising given that these blanching treatments were gentle.

Colour analysis (Table 1) showed a significant decrease in $a^{*}$ for the grapes blanched with microwaves, while $\mathrm{b}^{*}$ increased significantly after both treatments. Lightness was affected by the treatments and a significant increase in $\mathrm{L}^{*}$ was observed for grapes treated with the traditional method, as well as those treated with microwaves. As a consequence, a significant increase in chroma $\left(\mathrm{C}^{*} \mathrm{ab}\right)$ was observed for both treatments; while hue angle $\left(\mathrm{h}^{*} \mathrm{ab}\right)$ decreased slightly during traditional blanching. The colour difference $\left(\Delta \mathrm{E}^{*}\right)$ was 12 units for MWB and 15 units for TB.

Mechanical properties often change during the processing of products for a variety of diverse reasons. In plants, the alteration of cells leads to loss of turgor pressure and a softening of tissues; while the gelatinization of starch, hydrolysis of pectin and dissolution of hemicelluloses also causes the softening of tissues. Figure 1 shows an example of the force vs. distance of penetration curves obtained from puncture tests on fresh, TB and MWB grapes. It can be seen that the shape of the curves varies considerably. Fresh grapes have a much steeper initial slope and a fracture peak that is reached at a shorter distance of penetration. A fracture force of $9.1 \pm 1.9 \mathrm{~N}$ and a slope of $1.5 \pm 0.4 \mathrm{~N} / \mathrm{mm}$ were registered for fresh grapes. For the traditionally blanched grapes, the values were $5.7 \pm 1.5 \mathrm{~N}$ and $0.6 \pm 0.1 \mathrm{~N} / \mathrm{mm}$ and for grapes treated with microwaves they were $8 \pm 2 \mathrm{~N}$ and $0.8 \pm 0.2 \mathrm{~N} / \mathrm{mm}$. 
The microwave treatment did not significantly affect the value of the maximum stress peak, whereas the traditional treatment reflected a lower resistance of these samples to fracture due to the mechanical test. In fact, most of the grapes blanched by immersion in hot water showed some skin damage. Moreover, the treated samples (traditional and microwave) were significantly more easily deformable (less steep curve) than the fresh grapes.

\section{Changes in the quality parameters of grapes and syrup during storage}

Figures 2-7 and tables 2-3 show the changes in the quality parameters analyzed in the grape syrup and in the grapes in syrup. Tartaric acid, TPh and antioxidant activity was not analyzed in the syrup at 0 storage days as it was not expected to find any value. Table 4 shows the comparison of commercial grapes in syrup with grapes produced experimentally by microwave and traditional blanching.

A significant increase in the ${ }^{\circ}$ Brix of the grapes (Fig. 2) was observed during storage, tending to stabilize with the soluble solids in the syrup. This slight increase was consistent with the results for water content (Fig. 3), which showed a significant decrease during storage. These changes can be attributed to a small amount of dehydration and the increase of sugar that occurs when the grapes are placed in the syrup with an initially lower water activity. Nevertheless, the observed compositional changes did not change significantly the water activity with storage.

The grapes showed significant changes in tartaric acid during storage (Fig. 4). Tartaric acid levels suffered a sharp decline on the first day of storage, namely $63 \%$ for grapes blanched by the traditional method and 53\% for the microwave method. Stabilisation occurred after seven days for both processing methods. It can be observed that some of this acid is incorporated into the syrup, although the decrease observed after four days indicates a degradation of the acid.

Figure 5 shows the change in the TPh content for grapes in syrup blanched by both methods, as well as for the syrups used in their conservation. In the case of the microwave blanched grapes, the decrease during storage became statistically significant from the seventh day of storage and reached $30 \%$ by the end of the studied period. For grapes blanched by the traditional method, the decrease was statistically significant from the beginning of storage and reached $45 \%$ by the end of the studied period. In the same way as the tartaric acid, total phenol content increased in the syrup during storage, confirming the exchange of components between the grapes and the solution. In fact, there was an increase until day seven and then levels began to decline.

The antioxidant activity values are shown in Figure 6. There was a significant decrease in this capacity (23\%) for grapes blanched by the traditional method during the first 24 hours of storage and then values remained stable. On the contrary, microwave blanched grapes did not show significant changes during storage. Antioxidant activity increased in the syrup, showing the highest value on the seventh day, as was the case for total phenols. Pectin totals did not change significantly during storage with an average of $250 \mathrm{mg}$ AGU/100 g fresh grape.

POD and PME were partially inactivated during the treatments, but showed a partial recovery during storage, especially in the case of PME (Fig. 7). Nevertheless, this enzyme activity decreased again at larger storage times.

There was a significant decrease in colour lightness from day 7-15 for grapes blanched with either method (Table 2). This may indicate that the grapes were browning. Given that enzymatic browning is normally caused by PPO and the fact that this enzyme was completely inactivated during storage, it would appear likely that a 
Maillard reaction was responsible for non-enzymatic browning. Such a reaction can occur even at room temperature, although slowly. A significant increase in the values of $a^{*}$ was observed for grapes blanched by the microwave method that increased from -5 (the final studied storage day). Changes in the $\mathrm{b}^{*}$ coordinate were small but significant, and inconsistent with the changes associated with storage time. This meant a change in the colour of the samples from fairly pure green-yellow hues towards less pure yellowred tones. Grapes blanched by the traditional method changed in the same direction, although these changes were less pronounced.

Force-deformation analysis revealed that the texture of blanched grapes softens during storage. Table 3 shows the values obtained during storage for the mechanical properties of samples blanched by the various methods. The ANOVAs revealed significant differences during the storage period for maximum force, distance at the maximum force and slope. Maximum force and the corresponding distance increased from the beginning of storage until day seven for samples subjected to either of the treatments. This increase could be explained by the initial dehydration suffered by the samples, commented on above. However, the most significant changes occur from day 15 of storage, when a major decline in the ratio of these two parameters occurs. This decline is associated with softening and decreased tissue deformability.

\section{Comparison of grapes blanched by TB and MWB with commercial ones.}

The grape products obtained by TB and MWB were compared with two commercial brands of grapes in syrup. The values of the samples processed in the laboratory after 21 days of storage were used for the comparison, assuming that the commercial products would have been at least as long on the shelves. Table 4 shows the result of this analysis. All measured parameters and compounds were similar in the three analyzed products, except in the case of tartaric acid. For the other components and parameters, as expected, the commercial products showed levels more similar to products blanched by the traditional method than by microwaves. For tartaric acid, it was observed that the commercial products had a higher level of tartaric acid (339 $\mathrm{mg} / 100 \mathrm{~g}$ of sample) than the MWB and TB grapes in syrup (between 141 and $147 \mathrm{mg} / 100 \mathrm{~g}$ of sample). This is caused by presence of an acidulant that was added to the syrup in the commercial grapes, as described in the label of the product.

As well as the grapes, the commercial syrups were compared with the syrups used to store the MWB and TB grapes. The comparison included parameters such as ${ }^{\circ}$ Brix, water activity, tartaric acid, total phenols and antioxidant activity. Table 5 includes the values obtained in the analysis performed on syrup samples from the two commercial brands after 21 days of storage. In this case, with the exception of soluble solid content, the results of all the parameters analyzed were significantly higher in the commercial syrup than in the samples blanched in the laboratory. It must be remembered that the commercial syrup contains E-330 (citric acid) unlike the non-commercial samples. This explains the higher tartaric acid content of the commercial products compared to the laboratory samples. A greater contact time of the grapes with the syrup could explain the higher total phenol content and antioxidant activity observed in the commercial syrup. In addition, the higher TA content of the commercial product may have also contributed to the antioxidant activity of the syrup and so avoided any major oxidation of phenols in the product.

\section{CONCLUSIONS}


Microwave treatment for blanching was effective only if the sample is immersed in water before application. Acidity decrease, colour change and increased deformability of the grapes observed due to blanching treatments were more affected when traditional heating was used. During storage, an exchange of water and soluble solutes between the grapes and the syrup was observed. The most important changes were related to the gain in sugars and the loss of tartaric acid and grape phenols. This exchange of compounds was stabilized from the seventh day of storage, so this time period would be recommended as a minimum before the distribution of the product. Microwave treatment supposed a greater stability of tartaric acid and total phenols during storage than conventional one, also as a greater antioxidant activity of the samples. Changes in colour and firmness were significant during storage for both processed grapes. From the obtained results, microwave treatment of sample immersed in water can be proposed as a good alternative to conventional heating in boiling water for grapes blanching.

\section{Acknowledgements}

The authors thank the Ministerio de Educación y Ciencia, the Fondo Europeo de Desarrollo Regional and the Consellería de Educación y Ciencia for the financial support given throughout the Projects AGL 2005-05994 and GV04A-394AGL200505994). The translation of this paper was funded by the Universidad Politécnica de Valencia, Spain.

\section{REFERENCES}

AOAC. 1997. Official Methods of Analysis (16th ed.) Washington, DC. Association of Official Analytical Chemists.

CANTOS, E., ESPÍN, J.C. and TOMÁS-BARBERÁN, F. 2002. Varietal differences among the polyphenol profiles of seven table grape cultivars studied by LC-DADMS-MS. Journal of Agricultural and Food Chemistry. (50) 5691-5696.

CASH, J.N., SISTRUNK, W, A. and STUTTE, C.A. 1976. Characteristics of Concord grape polyphenol oxidase involved in juice color boos loss. Journal of Food Science. Chicago (41) 1398-1402.

ELEZ-MARTÍNEZ, P., AGUILÓ-AGUAYO, P. and MARTÍN-BELLOSO, O. 2006. Inactivation of orange juice peroxidase by high intensity pulsed electric fields as influenced by process parameters. Journal of the Science of Food and Agriculture. (86) 71-81.

FILIZ, IÇIER., HASAN, YIELDIZ. and TANER, BALSAN. 2008. Polyphenol oxidase deactivation kinetics during ohmic heating of grape juice. Journal of Food Engineering. 85 (2008) 410-417.

HEDDLESON, R.A. and DOORES, S. 1994. Factors affecting microwave heating of foods and microwaves induced destruction of food borne pathogens - a review. Journal of Food Protection. 57 (11), 1025-1037.

KIDMOSE, U. and MARTENS, H.J. 1999. Changes in texture, microstructure and nutritional quality of carrot slices during blanching and freezing. Journal of the Science of Food and Agriculture. 79 (12), 1747-1753.

KIMBALL, D.A. 1999. Citrus Processing. A complete guide, $2^{\text {nd }}$ Ed. Kluver Academic/Plenum Publishers, New York. 117-125. 
LI, B.B., SMITH, B. and HOSSAIN M.M. 2006. Extraction of phenolics from citrus peels: I. Solvent extraction method. Separation Purification Technology. (48) 182188.

LIN, S. and BREWER, M.S. (2005) Effects of blanching method on the quality characteristics on frozen peas. Journal of Food Quality. (28) 350-360. In Fruit Phenolics. Boca Ratón, Fl: CRC Press 1-98.

PEIRÓ, R.; DÍAZ, V.M.C.; CAMACHO M.M. and MARTÍNEZ-NAVARRETE, N. 2006. Micronutrient flow to the osmotic solution during the grapefruit osmotic dehydration Journal of Food Engineering, 74 (3) 299-307

PHILIPPON, J. 1984. Méthodes de blanchiment-refrodissement des legumes destines la congêlation. Science des Aliments. (4) 523-550.

PONNE, C.T., VAN REMMEN, H.H.J. and BARTELS, P.V. 1991. Application of electromagnetic energy in processing of whole potatoes. Voedingsmiddelentechnologie. 24 (21) 44-46.

RAMASWANY, H. and VAN DE VOORT, F.R. 1990. Microwave application in food processing. Canadian Institute of Food Science and Technology Journal. 23(1) 17-23.

RAPEANU, G.; ANN, V.L., CHANTAL, S. and HENDRICKX, M. 2006. Biochemical characterization and process stability of polyphenol oxidase extracted from Victoria grapes. Food Chemistry. (94) 253-261.

RE, R., PELLEGRINI, N., PROTEGGENTE A., PANNALA N., YANG M. and RICEEVANS C. 1999. Antioxidant activity applying an improved ABTS radical cation decolorization assay. Free Radical Biology \& Medicine. (26) 1231-1237.

REXOVA-BENKOVA, L. and MARCOVICH, O. 1976. Pectic enzymes. In R. S. Tipson and D.Horton (Eds) Advanced in Carbohydrate Chemistry and Biochemistry. New York, London: Academic Press. (33) 323-385.

SEVERINI C., DE PILLI, T., BAIANO, A., MASTROCOLA, D. and MASSINI, R. 2001. Study of preventing enzymatic browning of potato by microwave blanching. Sciences des aliments. 21(2) 149-160.

VALERO, E., VARÓN, R. and CARMONA, G.F. 1988. Characterization of polypenoloxidase from Airen grape. Journal of Food Science. Chicago (53) 14821485.

VIÑA, Z.S., OLIVERA D.F., MARANI, C.M., FERREYRA R.M., MUGRIDGE, A., CHAVES A.R. and MASCHERONI, R.H. 2007. Quality of Brussels sprouts (Brassica oleracea L. gemmifera DC) as affected by blanching method. Journal of Food Engineering. (80) 218-225.

WALKER, J.R.L. 1995. Enzymatic browning in fruits. In C. Y. Lee, \& J. R. Whitaker (Eds), Enzymatic browning and its prevention. USA: American Chemical Society. 822.

WHITAKER, J.R. 1972. Principles of enzymology for the food science. New York Marcel Dekker Inc.

YOKOTSUKA, K. and SHIMIZU, T. 1991. Polyphenol oxidase from six mature grape varieties and their activities towards various phenols. Journal of Fermentation Bioengineering. Osaka (71) 156-162.

YU, L., REITMEIEIR, C,A. and LOVE, M.H. 1996. Strawberry Texture and Pectin Content as affected by Electron Beam Irradiation. Journal of Food Science. 844-846.

ZHANG, M., TANG, J., MUJUMDAR, A.S. and WANG, S. 2006. Trends in microwave-related drying of fruits and vegetables. Food Science \& Technology. (17) 524-534. 
FIGURE 1.

EXAMPLE OF FORCE-DEFORMATION CURVES FOR FRESH GRAPES (FG), AND GRAPES BLANCHED BY THE TRADITIONAL (TB) AND MICROWAVE (MWB) METHOD.

FIGURE 2.

CHANGES IN THE SOLUBLE SOLIDS OF THE GRAPE SYRUP AND THE GRAPES IN SYRUP BLANCHED BY THE TRADITIONAL (TB) AND MICROWAVE (MWB) METHOD DURING THE STORAGE PERIOD. DIFFERENT LETTERS INDICATE SIGNIFICANT DIFFERENCES BETWEEN SAMPLES $(\mathrm{P}<0.05)$.

FIGURE 3.

CHANGES IN MOISTURE CONTENT OF THE GRAPES IN SYRUP BLANCHED BY THE TRADITIONAL (TB) AND MICROWAVE (MWB) METHOD DURING THE STORAGE PERIOD. DIFFERENT LETTERS INDICATE SIGNIFICANT DIFFERENCES BETWEEN SAMPLES $(\mathrm{P}<0.05)$.

FIGURE 4.

CHANGES IN THE LEVELS OF TARTARIC ACID (TA) IN THE GRAPES SYRUP AND THE GRAPES IN SYRUP BLANCHED BY THE TRADITIONAL (TB) AND MICROWAVE (MWB) METHOD DURING THE STORAGE PERIOD. DIFFERENT LETTERS INDICATE SIGNIFICANT DIFFERENCES BETWEEN SAMPLES $(\mathrm{P}<0.05)$.

FIGURE 5.

CHANGES IN THE TOTAL PHENOL CONTENT IN THE FRESH GRAPES AND THE GRAPES IN SYRUP BLANCHED BY THE TRADITIONAL (TB) AND MICROWAVE (MWB) METHOD DURING THE STORAGE PERIOD. DIFFERENT LETTERS INDICATE SIGNIFICANT DIFFERENCES BETWEEN SAMPLES $(\mathrm{P}<0.05)$.

FIGURE 6.

CHANGES IN THE ANTIOXIDANT ACTIVITY (AOA) OF THE GRAPE SYRUP AND THE GRAPES IN SYRUP BLANCHED BY THE TRADITIONAL (TB) AND MICROWAVE (MWB) METHOD DURING THE STORAGE PERIOD. DIFFERENT LETTERS INDICATE SIGNIFICANT DIFFERENCES BETWEEN SAMPLES $(\mathrm{P}<0.05)$.

FIGURE 7.

CHANGES IN PECTINMETHYLESTERASE (PME) AND PEROXIDASE (POD) OF GRAPES IN SYRUP BLANCHED BY THE TRADITIONAL (TB) AND MICROWAVE (MWB) METHOD DURING THE STORAGE PERIOD. DIFFERENT LETTERS INDICATE SIGNIFICANT DIFFERENCES BETWEEN SAMPLES $(\mathrm{P}<0.05)$. 
TABLE 1.

MEAN AND STANDARD DEVIATION (IN BRACKETS) OBTAINED FROM THE ANALYSIS OF FRESH GRAPES (FG) AND GRAPE BLANCHED BY THE MICROWAVE METHOD (MWB) AND BY THE TRADITIONAL METHOD (TB).

TABLE 2.

MEAN AND STANDARD DEVIATION (IN BRACKETS) OBTAINED FROM THE ANALYSIS OF THE COLOUR OF GRAPES STORED IN SYRUP AND PREVIOUSLY BLANCHED BY THE MICROWAVE METHOD (MWB) AND BY THE TRADITIONAL METHOD (TB).

TABLE 3.

MEAN AND STANDARD DEVIATION (IN BRACKETS) OBTAINED FROM THE ANALYSIS OF THE MECHANICAL PROPERTIES OF GRAPES BLANCHED BY THE MICROWAVE METHOD (MWB) AND BY THE TRADITIONAL METHOD (TB). $F_{f}$ : fracture force; $D$ : penetration distance at $F_{f}$.

TABLE 4.

COMPARISON OF MEAN VALUES OF COMMERCIAL GRAPES IN SYRUP (CP) WITH GRAPES PRODUCED EXPERIMENTALLY BY MICROWAVE BLANCHING (MWB) AND TRADITIONAL BLANCHING (TB) AND STORED IN SYRUP FOR 21 DAYS AT ROOM TEMPERATURE.

TABLE 5. 
MEAN AND STANDARD DEVIATION (IN BRACKETS) OBTAINED FROM THE ANALYSIS OF THE SYRUP IN A COMMERCIAL PRODUCT AND SYRUP USED FOR STORING GRAPES BLANCHED BY THE MICROWAVE METHOD (MWB) AND BY THE TRADITIONAL METHOD (TB). 




Figure 6. 
TABLE 1.

\begin{tabular}{cccc}
\hline Analysis & FG & MWB & TB \\
\hline Water content (g/g) & $0.820(0.001)^{\mathrm{c}}$ & $0.825(0.002)^{\mathrm{b}}$ & $0.836(0.002)^{\mathrm{a}}$ \\
${ }^{\circ}$ Brix (g/100 g) & $16.4(0.05)^{\mathrm{b}}$ & $16.7(0.05)^{\mathrm{a}}$ & $15.4(0.05)^{\mathrm{c}}$ \\
$\mathrm{a}_{\mathrm{w}}$ & $0.973(0.003)^{\mathrm{a}}$ & $0.971(0.003)^{\mathrm{a}}$ & $0.974(0.003)^{\mathrm{a}}$ \\
Tartaric acid (mg /100g) & $519(22)^{\mathrm{c}}$ & $409(12)^{\mathrm{a}}$ & $459(4)^{\mathrm{b}}$ \\
AOA (mg TEAC/100g) & $30(3)^{\mathrm{a}}$ & $25(5)^{\mathrm{a}}$ & $35(5)^{\mathrm{a}}$ \\
TPh (mg GAE/100g) & $69(10)^{\mathrm{a}}$ & $60(23)^{\mathrm{a}}$ & $71(12)^{\mathrm{a}}$ \\
TP (mg AGU/100g) & $260(31)^{\mathrm{a}}$ & $261(50)^{\mathrm{a}}$ & $211(44)^{\mathrm{a}}$ \\
$\mathrm{L}^{*}$ & $46(4)^{\mathrm{a}}$ & $57(3)^{\mathrm{b}}$ & $59.5(1.6)^{\mathrm{c}}$ \\
$\mathrm{a}^{*}$ & $-3.5(1.1)^{\mathrm{b}}$ & $-5(0.6)^{\mathrm{a}}$ & $-3.1(0.4)^{\mathrm{b}}$ \\
$\mathrm{b}^{*}$ & $16(3)^{\mathrm{a}}$ & $21(3)^{\mathrm{b}}$ & $20.8(1.9)^{\mathrm{b}}$ \\
$\mathrm{C}^{*}{ }_{\mathrm{ab}}^{\mathrm{b}}$ & $68(22)^{\mathrm{a}}$ & $117(31)^{\mathrm{b}}$ & $111(19)^{\mathrm{b}}$ \\
$\mathrm{h}^{*}{ }_{\mathrm{ab}}^{\mathrm{a}}$ & $102(3)^{\mathrm{a}}$ & $103.0(1.6)^{\mathrm{a}}$ & $99(2)^{\mathrm{b}}$ \\
\hline
\end{tabular}

Different letters in the same row indicate significantly different according to the ANOVA performed.

AOA : Antioxidant activity

TPh: Total phenols

TP: Total pectin 
TABLE 2.

\begin{tabular}{|c|c|c|c|c|c|}
\hline $\begin{array}{c}\text { Storage } \\
\text { days }\end{array}$ & $\mathrm{L}^{*}$ & $a^{*}$ & $\mathrm{~b}^{*}$ & $\mathrm{C}^{*} \mathrm{ab}$ & $\mathrm{h}^{*}{ }_{\mathrm{ab}}$ \\
\hline \multicolumn{6}{|c|}{ Traditional Blanching } \\
\hline 0 & $59.5(1.6)^{\mathrm{a}}$ & $-3.1(0.4)^{\mathrm{a}}$ & $20.8(1.9)^{\mathrm{d}}$ & $111(19)^{\mathrm{d}}$ & $99(2)^{\mathrm{c}}$ \\
\hline 1 & $61.9(1.2)^{\mathrm{d}}$ & $-3.7(0.6)^{\mathrm{a}}$ & $18(3)^{\mathrm{c}}$ & $90(28)^{c}$ & $102(3)^{\mathrm{d}}$ \\
\hline 4 & $61(1.5)^{c . d}$ & $-2.3(0.5)^{b}$ & $16(1.6)^{\mathrm{b}}$ & $66(13)^{a . b}$ & $98.2(1.9)^{\mathrm{b.c}}$ \\
\hline 7 & $62(4)^{\mathrm{d}}$ & $-1.5(0.7)^{\mathrm{c}}$ & $16(4)^{\text {b.c }}$ & $72(39)^{\text {b.c }}$ & $96(3)^{b}$ \\
\hline 15 & $52.2(1.1)^{\mathrm{a}}$ & $-0.5(1.2)^{\mathrm{d}}$ & $13.4(0.6)^{\mathrm{a}}$ & $45(4)^{\mathrm{a}}$ & $92(5)^{\mathrm{a}}$ \\
\hline 21 & $56(1.8)^{\mathrm{b}}$ & $-0.1(1.1)^{\mathrm{d}}$ & $17(2)^{\mathrm{b.c}}$ & $70(19)^{b}$ & $90(4)^{\mathrm{a}}$ \\
\hline \multicolumn{6}{|c|}{ Microwave Blanching } \\
\hline 0 & $57(3)^{\mathrm{c}}$ & $-5.0(0.6)^{\mathrm{a}}$ & $21(3)^{\mathrm{c}}$ & $117(31)^{\mathrm{b}}$ & $103(1.6)^{\mathrm{c}}$ \\
\hline 1 & $57(3)^{\text {b.c }}$ & $1.1(2)^{\mathrm{b}}$ & $21(2)^{\mathrm{c}}$ & $108(22)^{b}$ & $88(5)^{b}$ \\
\hline 4 & $57(3)^{\mathrm{c}}$ & $0.9(0.3)^{b}$ & $18.2(1.5)^{a . b}$ & $86(16)^{\mathrm{a}}$ & $88(9)^{b}$ \\
\hline 7 & $55(3)^{b}$ & $3.7(1.8)^{c}$ & $17.8(1.1)^{\mathrm{a}}$ & $83(10)^{a}$ & $78(6)^{\mathrm{a}}$ \\
\hline 15 & $50(3)^{\mathrm{a}}$ & $2(2)^{b}$ & $18(1.6)^{\mathrm{a}}$ & $84(14)^{a}$ & $83(5)^{b}$ \\
\hline 21 & $48(3)^{\mathrm{a}}$ & $5(1.5)^{c}$ & $20(3)^{\text {b.c }}$ & $105(27)^{\mathrm{C}}$ & $75(4)^{\mathrm{a}}$ \\
\hline
\end{tabular}

The different letters in the same column indicate significantly different according to ANOVA performed. 
TABLE 3.

\begin{tabular}{ccccccc}
\hline Storage & \multicolumn{3}{c}{ Traditional Blanching } & \multicolumn{3}{c}{ Microwave Blanching } \\
\cline { 2 - 6 } days & $\mathrm{Ff}_{\mathrm{f}}(\mathrm{N})$ & $\mathrm{D}(\mathrm{mm})$ & $\mathrm{F}_{\mathrm{f}} / \mathrm{D}$ & $\mathrm{F}_{\mathrm{f}}(\mathrm{N})$ & $\mathrm{D}(\mathrm{mm})$ & $\mathrm{F}_{\mathrm{f}} / \mathrm{D}$ \\
0 & $8(2)^{\mathrm{b}}$ & $10(2)^{\mathrm{a}}$ & $0.7(0.2)^{\mathrm{b} . \mathrm{c}}$ & $5.7(1.5)^{\mathrm{b}}$ & $9.8(0.8)^{\mathrm{b}}$ & $0.6(0.1)^{\mathrm{c}}$ \\
1 & $12(3)^{\mathrm{c}}$ & $13(1.6)^{\mathrm{c}}$ & $0.9(0.1)^{\mathrm{d}}$ & $7.1(1.3)^{\mathrm{b} . c}$ & $10.7(1.5)^{\mathrm{b}}$ & $0.65(0.12)^{\mathrm{c}}$ \\
3 & $11(3)^{\mathrm{c}}$ & $12.4(1.2)^{\mathrm{b} . \mathrm{c}}$ & $0.9(0.2)^{\mathrm{c} . \mathrm{d}}$ & $6.8(1.6)^{\mathrm{b} . c}$ & $10.1(0.8)^{\mathrm{b}}$ & $0.7(0.1)^{\mathrm{c}}$ \\
7 & $10(3)^{\mathrm{c}}$ & $12.9(1.4)^{\mathrm{c}}$ & $0.8(0.1)^{\mathrm{b} . c}$ & $8(4)^{\mathrm{c}}$ & $11.2(1.9)^{\mathrm{b}}$ & $0.6(0.2)^{\mathrm{c}}$ \\
15 & $7.6(2)^{\mathrm{b}}$ & $10.9(0.7)^{\mathrm{a} . \mathrm{b}}$ & $0.6(0.1)^{\mathrm{b}}$ & $1.9(1.3)^{\mathrm{a}}$ & $6.9(1.9)^{\mathrm{a}}$ & $0.23(0.15)^{\mathrm{b}}$ \\
21 & $4.9(1.4)^{\mathrm{a}}$ & $11.6(2)^{\mathrm{b} . \mathrm{c}}$ & $0.4(0.7)^{\mathrm{a}}$ & $0.6(0.3)^{\mathrm{a}}$ & $7.4(4)^{\mathrm{a}}$ & $0.08(0.03)^{\mathrm{a}}$ \\
\hline
\end{tabular}

The different letters in the same column indicate significantly different according to ANOVA performed. 
TABLE 4.

\begin{tabular}{|c|c|c|c|}
\hline Analysis & CP (Grape) & MWB & TB \\
\hline Water content (g/g) & $0.798(0.014)^{\mathrm{a}}$ & $0.803(0.001)^{\mathrm{a}}$ & $0.82(0.001)^{\mathrm{a}}$ \\
\hline $\mathrm{a}_{\mathrm{w}}$ & $0.976(0.003)^{c}$ & $0.970(0.003)^{\mathrm{a}}$ & $0.973(0.003)^{\mathrm{b}}$ \\
\hline${ }^{\circ}$ Brix (g/100g) & $17.5(0.05)^{\mathrm{a}}$ & $18.1(0.05)^{b}$ & $17.0(0.6)^{\mathrm{a}}$ \\
\hline Tartaric acid (mg /100g) & $339(8)^{\mathrm{b}}$ & $147(5)^{\mathrm{a}}$ & $141(0.5)^{\mathrm{a}}$ \\
\hline Total phenols (mg GAE/100g) & $36.2(1.4)^{\mathrm{a}}$ & $47(3)^{b}$ & $38(2)^{\mathrm{a}}$ \\
\hline $\begin{array}{c}\text { Antioxidant activity (mg } \\
\text { TEAC/100g) }\end{array}$ & $20(4)^{\mathrm{a}}$ & $30(1)^{b}$ & $25(3)^{a . b}$ \\
\hline Total pectin (mg de AGU/100g) & $252(26)^{\mathrm{a}}$ & $197(19)^{\mathrm{a}}$ & $202(40)^{\mathrm{a}}$ \\
\hline $\mathrm{L}^{*}$ & $52(4)^{b}$ & $48(1.8)^{\mathrm{a}}$ & $56(3)^{b}$ \\
\hline$a^{*}$ & $-1.1(1.1)^{\mathrm{a}}$ & $5.1(1.5)^{\mathrm{b}}$ & $-0.1(1.2)^{\mathrm{a}}$ \\
\hline$b^{*}$ & $13(4)^{\mathrm{a}}$ & $20(3)^{c}$ & $17(2)^{\mathrm{b}}$ \\
\hline $\mathrm{C}^{*}{ }_{\mathrm{ab}}$ & $48(28)^{\mathrm{a}}$ & $90(4)^{b}$ & $60(19)^{\mathrm{a}}$ \\
\hline $\mathrm{h}_{\mathrm{ab}}$ & $95(7)^{b}$ & $76(4)^{\mathrm{a}}$ & $105(27)^{c}$ \\
\hline Fracture force $(\mathrm{N})$ & $2.4(0.7)^{\mathrm{b}}$ & $5.2(1.7)^{\mathrm{c}}$ & $0.6(0.3)^{\mathrm{a}}$ \\
\hline Distance (mm) & $6(2)^{\mathrm{a}}$ & $12(2)^{b}$ & $7(4)^{\mathrm{a}}$ \\
\hline Fracture force/distance $(\mathrm{N} / \mathrm{mm})$ & $0.44(0.16)^{\mathrm{b}}$ & $0.43(0.09)^{\mathrm{b}}$ & $0.08(0.03)^{\mathrm{a}}$ \\
\hline
\end{tabular}

Different letters in the same row indicate significantly different according to the ANOVA performed. 
TABLE 5.

\begin{tabular}{|c|c|c|c|}
\hline Analysis & MWB & TB & Comercial Product (Syrup) \\
\hline${ }^{\circ}$ Brix & $18.1(0.05)^{\mathrm{c}}$ & $17(0.05)^{\mathrm{a}}$ & $17.5(0.05)^{\mathrm{b}}$ \\
\hline $\begin{array}{l}\text { Water activity } \\
\qquad\left(\mathrm{a}_{\mathrm{w}}\right)\end{array}$ & $0.973(0.003)^{\mathrm{a}}$ & $0.974(0.003)^{\mathrm{a}}$ & $0.977(0.003)^{\mathrm{b}}$ \\
\hline $\begin{array}{l}\text { Tartaric acid } \\
\text { (mg/100g of } \\
\text { syrup) }\end{array}$ & $160(5)^{\mathrm{a}}$ & $151(5)^{\mathrm{a}}$ & $335(9)^{b}$ \\
\hline $\begin{array}{l}\text { Total phenols (mg } \\
\text { GAE/100g syrup) }\end{array}$ & $6.8(0.13)^{b}$ & $6.1(0.2)^{\mathrm{a}}$ & $10.3(0.5)^{\mathrm{c}}$ \\
\hline $\begin{array}{l}\text { Antioxidant } \\
\text { activity (mg } \\
\text { TEAC/100g } \\
\text { syrup) }\end{array}$ & $11(3)^{b}$ & $4(3)^{\mathrm{a}}$ & $26.7(0.6)^{\mathrm{c}}$ \\
\hline
\end{tabular}

